\title{
Meaning More than They Say: The Conflict between YHWH and Jonah*
}

\author{
ROB BARRETT \\ Georg-August-Universität, Theologische Fakultät, Platz der Göttinger Sieben 2, 37073 \\ Göttingen, Germany
}

\begin{abstract}
Interpretations of the book of Jonah regularly focus on the prophet's explanation of his flight in 4.2 and YHWH's explanation of the qiqayon in 4.10-11 to illuminate the main characters' conflict. However, neither speech is particularly explanatory. Additionally, closer examination of Jonah's words is suggested by his ironic and self-implicating speech elsewhere in the book. YHWH's logic relating the qiqayon to Nineveh is also far from transparent. The reader is left to work out the nature of their conflict. In this article it is argued that the book focuses less on YHWH's relationship with Nineveh than on pressing Jonah to recognize YHWH's compassion for him, and that he is the only one in the entire world of the book that is unresponsive to YHWH.
\end{abstract}

Keywords: Jonah, irony, argumentum a fortiori, qal wahomer, qiqayon, Nineveh, direct speech.

* This study was written as part of the Sofja Kovalevskaja project on early Jewish monotheisms supported by the Alexander von Humboldt Foundation and the German Federal Ministry of Education and Research. 
Robert Alter counsels special attention to the direct speech of characters in Hebrew narrative, for such is 'the chief instrument for revealing the varied and at times nuanced relations of the personages to the actions in which they are implicated'. ${ }^{1}$ For the book of Jonah, while the extensive and growing number of interpretations testifies to the complexity and nearly limitless possibilities of this little book, and while no single reading can do justice to its multivalency, in my view previous readings have failed to attend properly to an important element of both Jonah's and God's direct speech, namely, that both at critical moments mean more than they say. Jonah does this inadvertently and ironically, while YHWH, I argue, does so with purpose.

It is regularly noted that Jonah's direct speeches are quite strange, ironic, self-undermining, incongruous, and so forth. ${ }^{2}$ Nonetheless, most interpreters rely heavily on the speech of 4.2 as a supposedly clear explanation for his flight in 1.3. Typical of many commentators, Alexander writes that 4.2 'provides at last the reason for his earlier attempt to evade his divine commission (1.3)'. ${ }^{3}$ Most read 4.2 as the closing of a longstanding gap that has puzzled the reader. ${ }^{4}$ It must be allowed, however, that 4.2 is not really an explanation at all. It is no explanation for Jonah to

1. Robert Ater, The Art of Biblical Narrative (New York: Basic Books, 1981), p. 66.

2. For example, Phyllis Trible (Rhetorical Criticism: Context, Method, and the Book of Jonah [Guides to Biblical Scholarship: Old Testament Series; Minneapolis: Augsburg Fortress, 1994]) describes Jonah's words as 'oblique' (p. 141), 'abound[ing] in ironies' (p. 141) and 'misrepresent[ing] the situation' (p. 171) and that 'his judgment... becomes a judgment against himself’ (p. 172). Philip Jenson (Obadiah, Jonah, Micah: A Theological Commentary [LHBOTS, 496; New York: T\&T Clark International, 2008]) similarly notes that each of Jonah's speech units is curious in various ways, but without drawing them together and using this observation for the larger interpretation of the book. Edwin M. Good (Irony in the Old Testament [Philadelphia: Westminster Press, 1965], p. 45) terms Jonah's speech of 1.9 as incongruous.

3. David W. Baker, T. Desmond Alexander and Bruce K. Waltke, Obadiah, Jonah and Micah (TOTC; Leicester: Inter-Varsity Press, 1988), p. 126. For a compilation of commentary along these lines, see Appendix 1 of Raymond F. Person, In Conversation with Jonah: Conversation Analysis, Literary Criticism, and the Book of Jonah (JSOTSup, 220; Sheffield: Sheffield Academic Press, 1996), pp. 171-86.

4. Meir Sternberg (The Poetics of Biblical Narrative: Ideological Literature and the Drama of Reading [Bloomington: Indiana University Press, 1987], pp. 318-20), in contrast, thinks the reason for Jonah's flight is obvious to the reader (Jonah is too tenderhearted to condemn the great city) until 4.2 shockingly sets straight the real reason for his disobedience. 
say that he fled his commission because of YHWH's character, for the connection remains obscure: what is it about YHWH's mercy and tendency to relent from disaster that makes flight the rational consequence? Magonet is correct to note that the speech 'does not resolve the initial question... It is still not clear to what he is actually objecting. '5 I argue that this speech fits a pattern for Jonah of twisted presentations of reality that illuminate his conflict with YHWH.

As for YHWH, the 'explanation' of the parable of the qiqayon (4.10-11) is also far from explanatory. While the grammatical structure of the comparison between the qiqayon and Nineveh is clear, the explicitly compared elements do not line up, as I discuss below. The difficulty with understanding YHWH's argument has even led some commentators to reject the traditional interpretation of v. 11 as a question. ${ }^{6}$ More importantly, the application of the 'lesson' beyond Nineveh is missing. If the point is YHWH's compassion on the great, evil city, who else should Jonah (or the reader) expect YHWH to treat similarly? By any reading, YHWH must mean more than is said.

In this study I propose a reading of the book of Jonah that takes these curiosities of speech seriously. By my reading, YHWH's initial movement toward restraining the wickedness of the powerful city of Nineveh through an oracle of doom is quickly overshadowed by Jonah's unexplained rejection of YHWH's commission. This YHWH-Jonah conflict becomes the dominant theme of the book as Jonah, acting as a representative for Israel, observes a world that understands the danger of opposing YHWH and quickly responds to his demands, while refusing to be responsive himself. Against so many universalistic interpretations of the book, in the end, the reader learns of YHWH's special commitment to his recalcitrant people. If YHWH is concerned with the ephemeral city of Nineveh, how much more has he demonstrated his commitment to Israel.

5. Jonathan Magonet, 'Jonah, Book of', in $A B D$, III, p. 941.

6. See Alan Cooper, 'In Praise of Divine Caprice: The Significance of the Book of Jonah', in Philip R. Davies and David J. A. Clines (eds.), Among the Prophets: Language, Image and Structure in the Prophetic Writings (JSOTSup, 144; Sheffield: Sheffield Academic Press, 1993), pp. 144-63; P. Guillaume, 'The End of Jonah is the Beginning of Wisdom', Bib 87.2 (2006), pp. 243-50. Ehud Ben Zvi ('Jonah 4:11 and the Metaprophetic Character of the Book of Jonah', JHS 9.5 [2009]: 1-13) suggests a bivalent reading. 


\section{The Primary Conflict}

I begin with a separate interpretational problem: the relationship between the book's two separable conflicts-YHWH vs. Nineveh and YHWH vs. Jonah. The two conflicts are introduced in rapid succession. YHWH announces the conflict with Nineveh in 1.2, which is resolved in 3.10 when the city repents and YHWH relents. The second conflict begins with Jonah's flight in 1.3. This one is left unresolved at the end of the book, for Jonah - unlike both the sailors and the Ninevites - has not yet given in to YHWH.

Most interpretations give priority to the conflict with Nineveh, resulting in readings that find the primary message of the book to concern YHWH's relationship with these representatives of the non-Israelite world. This position is quite weak, however. First, the conflict with Nineveh is unspecific and flat. YHWH's problem with the city is described in the most general terms: the Ninevites are 'evil' (1.2). Further explanation of the conflict is completely blanked - not gapped - by the narrator because it is unimportant for the story, which is not really about Nineveh at all. ${ }^{7}$ The plot does not depend on the reasons for the conflict with Nineveh, merely on the existence of that conflict. The YHWH-Nineveh conflict is then resolved in the most featureless way imaginable: the king orders the people to turn from their evil ways and from the violence of their hands (3.8). YHWH relents and the conflict recedes (3.10). The Ninevites are not even informed of YHWH's relenting. ${ }^{8}$ The conflict is utterly flat, as are the Ninevites as characters. They receive no portrayal beyond the moment of repentance, gaining no commendation like Ruth or Naaman the Aramean (2 Kgs 5.18-19) and garnering no sympathy or favor from the reader. Nineveh disappears almost completely from view in chs. 1, 2, and 4. Its importance arises again in ch. 4 only because it is the issue that illuminates the primary conflict with Jonah.

Interpretations that focus on the conflict with Nineveh also devalue the encounter between YHWH and the sailors in ch. 1. The regularly noted parallel structure of chs. 1 and 3 suggests the comparable significance of the sailors. ${ }^{9}$ Jonah's relatively deep interaction with the sailors-much

7. Interpretation often depends on discerning the difference between these two different types of lacunae: relevancies ('gaps') and irrelevancies ('blanks'). See Sternberg, Poetics, p. 236.

8. Noted by Thomas M. Bolin, 'Jonah 4,11 and the Problem of Exegetical Anachronism', SJOT 24.1 (2010), pp. 99-109 (104).

9. On the symmetric structure of the book, see Trible, Jonah, pp. 109-20. 
more probing than that with the Ninevites, resulting in 'rounder' characterization - demands that they be treated as significant contributors to the theme of the narrative. But if YHWH's continuing relationship with the Ninevites is obscure, any lasting effect of the sailors' experience is completely absent from the narrative. If YHWH has enduring concern for non-Israelites, the sailors do not seem to garner any.

When the conflicts with the Ninevites (and sailors) are granted priority, the interpretation of the book leads inexorably toward the radical idea that YHWH enters into meaningful relationship with non-Israelite peoples, which results in an overwhelmingly weighty theological burden for such a difficult and brief book. Do the sailors abandon their other gods? Are the Ninevites given their own Torah? Does Israel remain unique within YHWH's world? The cartoon-like responsiveness of both the sailors and the Ninevites disallows any exploration of where their relationship with YHWH might go beyond the pages of this text.

What then is the nature of YHWH's conflict with Jonah? In the structurally parallel encounters with the sailors and the Ninevites, the strikingly consistent contrast with Jonah is that the other human characters are immediately consumed with fear of the dangerous implications of resisting YHWH's will and power while Jonah consistently exhibits no concern and stubbornly twists his neck away from the direction of YHWH's leading. The sailors discover the impotence of their gods in the midst of YHWH's storm as they try everything at their disposal to avert disaster. They are willing to abandon their valuable cargo and even go against their consciences by casting Jonah into the sea in response to the prophet's (dubious) word, while Jonah ignores the life-threatening storm in an apparent desire to die rather than accede to YHWH's will. ${ }^{10}$ The Ninevites, unaware even of YHWH's name, respond instantaneously to the oracle of doom as the scales fall from their eyes, they perceive their wickedness, and enact a repentance of changed ways. The king cedes authority to Jonah's God by exchanging his signs of authority for those of repentance. The sailors display responsiveness to YHWH in the cultic domain of prayer, sacrifice, and vows. In contrast to the sailors' praiseworthy cult, Jonah offers what appear to be an infelicitous prayer and unrealized promises of sacrifice and vows (see below). His 'cult' lacks the existential reality of the sailors'. Nineveh, complementarily, displays

10. Terry Eagleton ('J.L. Austin and the Book of Jonah', New Blackfriars 69.815 [2007], pp. 164-68 [164]) suggests an interesting alternative reading: Jonah attempts suicide to force YHWH to save him. 
responsiveness in the moral domain by turning from wickedness and violence. While the Ninevites exhibit no resistance to changing their behavior in the face of threat, Jonah persists in his resistance to YHWH regardless of threat. Both the Ninevites and sailors act to satisfy YHWH in order not to perish, but Jonah would prefer to die.

The non-human characters of the narrative likewise display a perfect responsiveness to YHWH's will. The storm, lot, fish, plant, worm, and desert wind all sing YHWH's tune while Jonah refuses. ${ }^{11}$ Rather than a high statement of divine sovereignty over the created order, ${ }^{12}$ this responsiveness is most simply interpreted as a portrayal of a world where everyone and everything is utterly responsive to YHWH except for Jonah. The focus of the book is not the situation wherein Jonah resists YHWH but the fact of his resistance. Interestingly, the universality of responsiveness - apart from Jonah - extends even as far as YHWH, who responds to the Ninevites when they turn from their wicked ways. More importantly, YHWH is responsive to Jonah in his rejection of the Ninevite mission, working with him to achieve his willing partnership. Even YHWH is cooperatively responsive, but not Jonah. This is the central conflict of the book.

\section{Jonah's Twisted Speech and 'Explanation' of His Flight}

Narrative critics have long recognized that human speech in biblical narrative must be treated cautiously and not read naïvely as indicating reality. As Alter wisely observes, 'Although a character's own statements might seem a straightforward enough revelation of who he is and what he makes of things, in fact the biblical writers are quite as aware as any James or Proust that speech... may be more a drawn shutter than an open window'. ${ }^{13}$ Suspicious reading of Jonah's speech is not an anachronistic postmodern imposition, but is necessitated by sensitivity to ancient genre.

11. Yael Shemesh ("“And Many Beasts" [Jonah 4:11]: The Function and Status of Animals in the Book of Jonah', JHS 10.6 [2010], pp. 13-14 and n. 45) summarizes the responsiveness of all of creation to YHWH: the fauna, flora, forces of nature, and even inanimate objects (the ship and the lots) perform as 'active agents' of YHWH.

12. E.g. Terence E. Fretheim, The Message of Jonah: A Theological Commentary (Minneapolis: Augsburg Fortress, 1977), p. 21; Shemesh, 'Beasts', p. 10.

13. Alter, The Art of Biblical Narrative, p. 117. Cf. also Shimeon Bar-Efrat's orderly exposition of characterization (Narrative Art in the Bible [Bible and Literature, 17; trans. D.S. Vanson; Sheffield: Almond Press, 1989], pp. 47-92). 
All seven instances of Jonah's direct speech present twisted views of reality that mean more than he says. ${ }^{14}$ Jonah's words curiously illuminate his conflict with YHWH.

In 1.9, having been exposed by the lot under the dire threat of the storm, Jonah testifies: 'I am a Hebrew...I fear YHWH, the God of heaven, who made the sea and the dry land'. In one sense, his answer is extraordinarily matter-of-fact. He identifies himself and his deity. But Jonah ironically connects himself to the one who has mastery over the sea - their current problem - and the dry land - their salvation. The problem of the sea is stressed repeatedly in the first half of Jonah: eleven other times in chs. 1-2. The safety of the dry land occurs twice more, once as the sailors desperately row for shore (1.13) and again when the fish deposits Jonah safely upon it (2.11 [ET 10]). Jonah speaks the theological key to their problem with no interest in turning it himself. Furthermore, Jonah's confession of fear of YHWH ironically underlines his lack of fear throughout the entire narrative. It is, rather, the sailors who fear the storm and call upon their gods (1.5), who fear even more greatly upon hearing Jonah's words (1.10), and whose fear turns to reverence when the storm is stilled (1.16). The structure of 1.4-16 underlines the transformation of the sailors' fear and Jonah's contrasting intransigence. ${ }^{15}$ Jonah's speech is truthful yet means more than he says. ${ }^{16}$

Later in the same scene, the fearful sailors ask Jonah about responding to the storm's danger: מה־נעשה לך (1.11)? Jonah replies, 'Pick me up and throw me into the sea' (1.12). Jonah answers the question, 'What should we do to you?', which is how most translations render the sailors' inquiry. However, this is not likely what they mean, for when Jonah suggests they kill him, the sailors voice a collective 'God forbid!' and redouble their efforts to row to safety (1.13). Had they been seeking to placate YHWH by harming Jonah, they would not have rejected his death-wish. Against the usual translation, the preposition $ל$ should be read as 'for you'. ${ }^{17}$ Their

14. Hermann J. Opgen-Rhein (Jonapsalm und Jonabuch: Sprachgestalt, Entstehungsgeschichte und Kontextbedeutung von Jona 2 [SBB, 38; Stuttgart: Verlag Katholisches Bibelwerk, 1997], pp. 117-18) notes that Jonah speaks more than he knows throughout the book.

15. Fretheim, Jonah, pp. 73-91.

16. Trible (Jonah, p. 141) characterizes this speech as 'abound[ing] in ironies of genre, setting, content, and structure'.

17. Ronald J. Williams, Hebrew Syntax: An Outline (Toronto: University of Toronto Press, 2nd edn, 1976), \$271 'Interest'. Of course, both readings of the preposition are possible (cf. negatively in 3.10 and positively in 4.5 ). 
question most logically would be what gift (or bribe) would entice Jonah to help them pacify his God. But Jonah reads it negatively and reasons that only his death will assuage YHWH. While he is correct insofar as his descent into the sea stops the storm, he severely misunderstands YHWH, who in no way seeks his death, but his responsive life.

Jonah's third speech, the psalm of ch. 2, has been the subject of much discussion..$^{18}$ Read in context, it is a fantastic example of Jonah's ability to twist reality — and the psalm traditions underlying his speech - in shocking ways. ${ }^{19}$ Lacking any confession, Jonah describes his journey from peril to salvation while remaining utterly silent about his refusal to respond to YHWH. He claims to have called to YHWH (2.3), ${ }^{20}$ but calling out is the one thing he has refused to do, either against Nineveh (1.2-3) or to his God (1.6). Although Jonah claims that YHWH has heard his voice, the narrative has YHWH acting of his own accord (2.1 [ET 1.17]). Jonah asserts that YHWH has cast him into the deep (2.4) when it was actually the sailors who did so and only reluctantly and according to Jonah's directions (1.12). ${ }^{21}$ Jonah expresses dismay at drowning for the sole reason that it means he will not see YHWH's temple again (2.5), which contradicts his goal of fleeing the presence of YHWH $(1.3,10){ }^{22}$ As is his tendency, Jonah's words have some connection to reality: he truly was in distress (2.3), drowning (2.4, 6-7), and YHWH did save him (2.7). However, he testifies that YHWH did so because of Jonah's praiseworthy remembrance of him (2.7-8) while the narrative has Jonah refusing to turn toward YHWH. But the height of Jonah's perverted poetry comes at the end when he contrasts himself with 'the worshipers of vain idols who abandon their covenant faithfulness' (2.9). It is quite obvious that Jonah is the one who fails to display faithfulness while the sailors who worship other gods are desperate to engage with the heavenly power that demands their attention. ${ }^{23}$ In a final ironic twist, Jonah promises to offer sacrifices

18. Summaries of the issues are in the standard commentaries. An exhaustive treatment is Opgen-Rhein, Jonapsalm.

19. Opgen-Rhein (Jonapsalm, pp. 112-17) discusses a number of these tensions under the category of irony.

20. In the remainder of this discussion of the psalm I refer to the MT versification.

21. John C. Holbert ("'Deliverance Belongs to Yahweh!": Satire in the Book of Jonah', JSOT 21 [1981], pp. 50-81 [71]) notes this and many other infelicities in Jonah's speech as part of characterizing the book as satire.

22. Cf. Holbert, 'Deliverance', p. 72.

23. Cf. Holbert, 'Deliverance', pp. 73-74. 
and to pay vows (2.10) - an empty promise he otherwise gives no evidence of honoring - when the sailors have already done these very things (1.16). Jonah speaks a twisted form of reality. In particular, he portrays YHWH as being faithfully responsive to Jonah's need and himself appropriately grateful when in reality it is Jonah who is obstinately unresponsive to YHWH while YHWH pursues Jonah to the depths of the sea to establish a responsive relationship. In reality, Jonah continues to sink in a sea of misapprehension, separated from both YHWH and his own salvation.

Jonah's fourth utterance, his sermon to Nineveh, is shockingly brief at five words (3.4). The sermon omits both the identity of YHWH as the offended deity and the nature of the Ninevites' offense. Its matter-of-fact style contains none of the pathos or persuasive expression characteristic of prophetic speech. The sermon's threat is also strange in its reference to a surprisingly long period of forty days, portraying destruction as a distant possibility rather than a pressing crisis..$^{24}$ But, despite its brevity, Jonah still speaks more than he knows through the oft-noted ambiguity in the verb הפך. It permits two divergent readings: either Nineveh's destruction or its repentance and reformation. ${ }^{25}$ While Jonah desires the former - as demonstrated in ch. 4-he ironically predicts the latter. Sasson suggests that Jonah here is a 'comic dupe' who does not understand the alternate explanation of his words and that 'it must have amused an audience to have a prophet who does not fully fathom his own predictions'. ${ }^{26}$ The main point, however, is the ironic contrast between his unconscious prediction of Nineveh's responsiveness and his own persistent unresponsiveness.

I return to the crucial speech of 4.2 below, but first consider Jonah's final two utterances. Jonah returns to the theme of death-wish, echoing his earlier attempt at drowning: 'Better is my death than my life' (4.8). When YHWH questions him about the propriety of his anger over the dead qiqayon, Jonah responds, 'Yes, angry enough to die' (4.9). The connection between Nineveh's reprieve, the sun and wind, the loss of the

24. Following MT, cf. R.W.L. Moberly, 'Preaching for a Response? Jonah's Message to the Ninevites Reconsidered', VT 53 (2003), pp. 156-68.

25. There is talmudic observation of this ambiguity (Jack M. Sasson, Jonah: A New Translation with Introduction, Commentary, and Interpretation [AB, 24B; New York: Doubleday, 1990], pp. 234-35, 237).

26. Sasson, Jonah, p. 346. 
qiqayon, and Jonah's death-wish is not at all clear. Though not unique (cf. Elijah in $1 \mathrm{Kgs} \mathrm{19.4;} \mathrm{Moses} \mathrm{in} \mathrm{Num.} \mathrm{11.15),} \mathrm{Jonah's} \mathrm{preference} \mathrm{for}$ death over life exhibits a stiff-necked resistance to YHWH in the strongest terms: YHWH has already refused Jonah's first attempt at death and persists in preserving him against his own wishes. Jonah's death-wish highlights YHWH's contrasting desire for his responsive life. Jonah wants to identify himself with the dead qiqayon, but YHWH determinedly values him more highly.

Finally, I return to 4.2. This speech, rather than clarifying Jonah's conflict with YHWH, only points to the problem. Given the tendency of Jonah's speech to reveal more than its surface meaning, it is surprising that most commentators read this creedal affirmation as straightforward and transparent: 'O YHWH! Is not this what I said while I was still in my own country? That is why I fled to Tarshish at the beginning; for I knew that you are a gracious God and merciful, slow to anger, and abounding in steadfast love, and ready to relent from punishing' (4.2). The reason for Jonah's flight at YHWH's initial command (1.3) has been a nagging background problem for the reader for three chapters as the bizarre struggle between YHWH and Jonah has developed. ${ }^{27}$ The most common understanding is that Jonah rejects YHWH's inclination to forgive and desires Nineveh be destroyed, thus fleeing rather than contributing to Nineveh's repentance. Jonah's response does not, however, say this. He makes no comment about Nineveh. This speech, as throughout the book, focuses on Jonah's own struggle with YHWH (and vice versa) rather than on Nineveh. The conflict with Nineveh only provides the stage upon which the drama between YHWH and Jonah plays out. Jonah complains about the character of YHWH, that the deity is too gracious, merciful, patient, and prone to relent - a unique sentiment in the Hebrew Bible. Even more striking is the fact that Jonah has survived his disobedience, his flight, the storm, and the fish only because of YHWH's grace, mercy, slowness to anger, steadfast love, and readiness to relent from punishing. But Jonah also speaks beyond himself to Israel as the prime beneficiary of YHWH's kindness. The obvious intertextual link with Exod. 34.6-7 makes the point. After the golden calf debacle, Israel's life

27. Shemesh ('Beasts', pp. 20-22) offers a recent and useful list of possibilities: Jonah's concern either to protect Israel from Assyria, to avoid having Nineveh's penance supersede Israel's, for his own safety, for his image as a prophet, for God's reputation as powerful enough to accomplish his threats, or for proper punishment of sinners. 
and relationship with YHWH was on the edge of extinction, but YHWH's tendency to relent saves Israel. ${ }^{28}$ Jonah unwittingly testifies to being the recipient, both personally and nationally, of YHWH's deeply committed and patient grace. Rather than explaining his displeasure at YHWH's attitude towards Nineveh, Jonah affirms the God with whom he struggles. Jonah's words bespeak YHWH's commitment to Jonah (and Israel) with a steadfast love that refuses to forsake. YHWH's particular commitment to Jonah is demonstrated throughout the entire book and particularly in the difficult interchanges of ch. 4, where Nineveh fades into the background. Jonah's confession in 4.2 does not so much explain his flight as continue his habit of testifying to his inability to comprehend YHWH's commitment to him.

\section{YHWH's Explanation of the qiqayon}

But what of YHWH's speech and, in particular, the object lesson of the qiqayon? I argue that this is not so much an attempt to convince Jonah to have compassion on Nineveh, but rather primarily functions to remind Jonah that YHWH is supremely concerned for Jonah (and Israel). Commentators nearly all agree that YHWH's rhetoric takes the basic form of an argumentum a fortiori (or qal wahomer). This rhetorical tool functions by presenting an obviously true smaller case that, once allowed by the hearer, compels assent to the greater case which stands in question. As usually interpreted, the smaller case is that of the qiqayon, which Jonah has demonstrated to be of importance to him and desired that it be spared. The greater case is that of Nineveh. Thus, if the qiqayon is valuable to Jonah, then Nineveh must be even more valuable to YHWH.

However, the oft-recognized problem is that the two halves of the argument do not align very well. Levine goes so far as to comment, 'To even the most casual reader, the analogy between the plant and the city is obviously unconvincing and untenable'. ${ }^{29}$ Simon writes, '[T]he Lord's rhetorical question is more emotional than logical' ${ }^{30}$ Cooper, arguing for

28. On this connection, see Thomas B. Dozeman, 'Inner-Biblical Interpretation of Yahweh's Gracious and Compassionate Character', JBL 108 (1989), pp. 207-23 (218-21).

29. Etan Levine, 'Jonah as a Philosophical Book', ZAW 96 (1984), pp. 235-45 (241). Levine supports this claim in a way complementary to mine, with some overlap.

30. Uriel Simon, Jonah: The Traditional Hebrew Text with the New JPS Translation (trans. Lenn J. Schramm; JPS Bible Commentary; Philadelphia: Jewish Publication Society, 1999), p. 41. 
a wholly different approach to YHWH's speech, goes further with his claim that 'the a fortiori reasoning allegedly found in God's statements in 4.10-11 makes no sense'. ${ }^{31}$ The qiqayon is described in three ways. Two stipulate Jonah's lack of involvement with it: he did not toil over it and he did not cause its increase. The third attribute of the plant is independent of Jonah: the qiqayon was ephemeral, appearing one day and disappearing the next. ${ }^{32}$ Using parallel grammar, Nineveh is also described with three attributes, none of which explicitly involve YHWH: it is a great city, contains 120,000 inhabitants who do not have basic understanding, and also contains many animals.

The standard interpretational move is to complete the comparison by filling in the missing elements. Simon spells this out explicitly:

You cared about the plant... which you did not work for and which you did not grow, which appeared overnight and perished overnight. And should I not care about Nineveh, that great city [which I nurtured and grew, which was built over many days and was not destroyed over many generations], in which there are more than twelve myriad persons who do not yet know their right hand from their left, and many beasts as well! ${ }^{33}$

Simon justifies his bracketed insertion as follows:

The common format of the two verses - similar introductory statements followed by two subordinate clauses introduced by a relative pronoun-makes it possible to leave part of the comparison unstated. Readers must complete it for themselves and attribute to the great city everything that does not pertain to the small plant. ${ }^{34}$

Of course, this approach requires even more additions because Nineveh's attributes should also be present in the qiqayon in some small, corresponding way. The city is great, which previously referred to its size (3.3; though remaining vague in 1.2 and 3.2) and this indeed could be applied to the large qiqayon; however, the omission of גדול in reference to the qiqayon is quite surprising since the adjective appears fourteen times in the little book. As to the number of inhabitants, it is difficult to understand

31. Cooper, 'Praise', pp. 157-59. Another helpful explanation of the illogic of the argument is in Gerda Elata-Alster and Rachel Salmon, 'The Deconstruction of Genre in the Book of Jonah: Towards a Theological Discourse', Journal of Literature and Theology 3 (1989), pp. 40-60 (56-57).

32. While the Hebrew idiom is obscure, this is undoubtedly the point.

33. Simon, Jonah, p. 45.

34. Simon, Jonah, p. 46. 
how a plant could be connected to a city in this way. Further, the qiqayon does not exhibit ignorance like the Ninevites. The lack of clear correspondence between the two halves of the argumentum a fortiori suggests that the device is rather clumsily employed, which is striking in light of the narrative's skillful design throughout.

Furthermore, the insertions Simon assumes from the reader require the injection of additional theological ideas not present elsewhere in the book and not significantly present in the traditions preserved in the larger Hebrew Bible. Has YHWH truly toiled over Nineveh? The verb עמל, a negative term of exertion and difficulty in the common plight of human suffering, is never used with YHWH as its subject. But if עמל is to be associated with YHWH, the verb would point to YHWH's toil over Israel, not Gentile cities or nations. In this narrative, YHWH toils over Jonah and only indirectly thereby over Nineveh. The Ninevites' repentance requires no toil, only the speaking of five words. On the other hand, throughout the Hebrew Bible YHWH toils over Israel. ${ }^{35}$

As for making great (גדל, piel), there is no indication that YHWH made Nineveh great. ${ }^{36}$ It simply is such, from the book's very beginning (1.2). According to biblical traditions, the entity made great by YHWH is Israel. Most famously in Gen. 12.2, YHWH affirms that Abraham is the one he will make into a great (גדול) nation and he promises to make Abraham's name great (גרל, piel). The book of Isaiah opens with YHWH's complaint that he has made Israel great (גדל, piel) and yet they have rebelled against him (1.2). The message of hope later in the book of Isaiah artistically portrays the mysterious enlarging of Israel so the post-exilic community is greater than before (49.19-21). While a generalized theology of creation might connect Nineveh's greatness to YHWH, it is by no means obvious within the book of Jonah or indeed the larger Hebrew Bible. In fact, for YHWH's argument to work in this way, the reader must already agree that YHWH has labored over and enlarged Nineveh. Otherwise, the argument is circular and assumes its conclusion from the beginning: that YHWH has an interest in Nineveh. ${ }^{37}$

35. A particularly interesting occurrence of the verb is Isa. 53.11, where it is exactly the suffering (עמל) of the servant that benefits Israel. Regardless of the servant's identity, YHWH himself here in some sense suffers and toils for Israel's benefit.

36. It could be argued that Ezek. 31.1-9, which describes the greatness of Assyria, implies that YHWH did this (v. 9), although the waters are given explicit credit (v. 4).

37. Ben Zvi ('Metaprophetic', p. 9) reads the argument 'backwards' to infer that Jonah's readers understood YHWH to have caused Nineveh to grow. 
Turning to the brief lifespan of the qiqayon, although the temporal horizon of Nineveh is undoubtedly wider than the plant, one might have difficulty finding a more short-lived city. Despite Nineveh's ancient roots and place in the table of nations (Gen. 10), it rose to significance only c. 700 BCE with Sennacherib's aggrandizement of it as his capital, before being utterly destroyed by the Babylonians in $612 \mathrm{BCE}$, never to be rebuilt. It thus had a period of significance of a meager c. 90 years. This was by no means a long-lasting city. From a moral perspective, the repentance of Nineveh highlighted in Jonah is so ephemeral that it is nowhere else recorded. Nineveh may have been responsive to YHWH one day, but it did not last long enough for anyone beyond Jonah and YHWH to notice. For the book's probable post-exilic audience, Nineveh's prestige has quickly disappeared, being replaced by Babylon, which was then replaced by Persia. Empires come and go, but it is Israel who perseveres because YHWH does not abandon his covenant faithfulness (cf. 2.9 [ET 8]), as indeed he does not abandon rebellious Jonah.

How then do the 120,000 Ninevite inhabitants and all of the animals relate to the qiqayon? Admittedly these seem to be of greater natural worth than the plant, but ending with the animals, which are rarely objects of sparing in the Bible, is certainly odd. ${ }^{38}$ The baby-like lack of discernment between right and left may inspire compassion but does not connect in any way to the qiqayon.

YHWH's explanation of the qiqayon demands that the reader fill gaps. The divine speech must mean more than it says. The traditional interpretation requires the reader add not only words connecting the plant and the city, but theological concepts as well. If the message of the book concerns YHWH's generalized compassion for non-Israelite peoples, this is also a required, gap-filling creation of the reader. I suggest that the reader complete the argument not in these ways, but by taking this peculiar argumentum a fortiori one step farther: to Israel, as symbolized by Jonah. All of the explicit features of both the qiqayon and Nineveh are gathered up in Israel, but even more so.

38. On Yhwh's compassion for animals, see Shemesh, 'Beasts', pp. 4-5 and n. 10. For a new and creative interpretation of the animals as sacrificial, see Bolin, 'Anachronism'. 
Figure 1. The Argument from the qiqayon

\begin{tabular}{|ccc|}
\hline & Explicit & Implicit \\
Jonah-qiqayon & YHWH-Nineveh & YHWH-Israel \\
No toil & $\longrightarrow$ वा & YHWH's long toil \\
Did not grow & YHwH grew \\
Ephemeral & & Long lasting \\
& & Greatest city \\
& Sand and stars \\
& Great city & Most ignorant \\
& More than 120,000 & Significant \\
& Ignorant & while also 'beastly' \\
& Insignificant animals & \\
& &
\end{tabular}

The argument can then be diagrammed as in Figure 1. The cited attributes of the qiqayon reach their apex in Israel. In the book, YHWH's primary toil is over Jonah, not Nineveh. Much more important, however, is YHWH's long-standing toil over his own people. Similarly, Israel is the nation that YHWH has grown and - especially within the Zion traditionoutlasts every transitory imperial power (e.g. 2 Sam. 7.13). ${ }^{39}$ The qualities articulated about Nineveh also apply to Israel. If Nineveh is a great city, Jerusalem is greater, even the greatest city of the world, set upon Zion, the tallest mountain in the world (Mic. 4.1; Zech. 14.10). Of course, this refers not to physical size, but to importance. If Nineveh can boast of 120,000 inhabitants, Israel is more numerous than sand and stars (Gen. 22.17). The number symbolism of twelve times ten thousand also brings Israel's twelve tribes to mind. ${ }^{40}$ Finally, Nineveh is filled with ignorant people, who do not know right from left. But Israel's ignorance is much greater than Nineveh's, as is so memorably articulated in Isa. 1.3 (following directly after YHWH's testimony that he has made the nation great in 1.2):

The ox knows its owner,

And the donkey its master's crib;

But Israel does not know,

My people do not understand.

39. Cf. here also the making of David's name great (גדול) like the great ones of the earth (2 Sam. 7.9).

40. I thank the anonymous JSOT reviewer for suggesting this connection. 
Israel's inability to understand goes beyond knowing the difference between right and left, extending as far as not recognizing its owner (i.e. YHWH) - as even an ox does - or even where it receives its basic sustenance (i.e. from YHWH) - as even a donkey knows. Ninevites may not know right from left, but they know what to do when faced with YHWH's wrath. Like the sailors, they respond immediately and know what to do. They do not even need to be told what their offense against YHWH is, but how many times has Israel ignored the words of its prophets? And if Nineveh's animals inspire YHWH to spare the city, Israel's animal-like ignorance is further reason for continued forbearance.

The apparently flawed comparison of the qiqayon and Nineveh functions powerfully as a two-pronged premise for the implied conclusion: YHWH spares Jonah and Israel. YHWH is devoted to Jonah, culminating in the unanswered question that ends the book, and really climaxing in the two unspoken but logically subsequent questions: 'Should I not spare Jonah, my prophet who desires death, whom I have labored over, in order to bring him to this place where he, too, can learn to respond to me? And should I not spare Israel who also chooses death (Deut. 30.19), that great and ignorant people, over whom I toiled and whom I grew, the people who have been my inheritance from times of old?' Jonah values himself no more highly than the qiqayon, hoping to wither similarly before the scorching east wind, but YHWH elevates him above even Nineveh. Will the Israelites call upon their God when facing the storm hurled upon them and their need for the safety of the dry land that YHWH rules? Will they offer sacrifices and vows to YHWH when the storm is calmed? Will they repent and change their evil ways when YHWH's prophets speak so powerfully about him, his concerns, and their danger of being overthrown? Will Israel's king disrobe and de-throne himself before YHWH in obeisance under the very present threat of destruction? As with Jonah's subtle speech, YHWH here points to central concerns that go beyond the actual words, beyond the surface conflict over Nineveh, and to the heart of the problem of being responsive to YHWH.

While this sort of two-step qal wahomer with an implied conclusion appears to be an unusually creative extension of the form, examples of both elements can be found in the Old Testament. By any reading, the conclusion of the book of Jonah is elided and such a device is a potent rhetorical form. In their famous introduction to logic, Arnauld and Nicole note that the rhetorical presentations of syllogisms ordinarily omit 
something (technically known as an enthymeme) 'since the nature of the human mind is rather to prefer that something be left it to supply, than to have it thought that it needs to be taught everything', ${ }^{41}$ While the syllogism's major or minor premise is sometimes omitted, it is often the conclusion itself. Edward H. Madden observes that this is the primary mode for employing proverbs, where 'if a person says, "Only a fool rushes in where angels fear to tread" the hearer, in context, supplies the minor, "You are rushing in, etc.", and further supplies the conclusion, "You are a fool".'42 The omission of the conclusion within a qal wahomer argument is important enough that R. Eliezer b. R. Jose the Galiliean created a separate rule for it within his thirty-two rules of interpretation. One biblical example he cites is Ps. 15.4, where the righteous are characterized as those 'who swear to their own hurt and do not change'. Left unstated is the conclusion: how much more will they stand by their oaths in other cases. ${ }^{43}$ Indeed more broadly, the art and power of much Hebrew parallelism revolve around requiring the audience to find connections left unstated. ${ }^{44}$

There are also biblical examples of fashioning a multistep qal wahomer for powerful rhetorical effect. In $1 \mathrm{Kgs} 8.27$, Solomon's core argument is that God cannot be contained by the heavens, so how much less can he dwell in the temple. But even the vastness of the heavens do not emphasize the point strongly enough for Solomon, who extends the figure by saying even the 'heavens of the heavens' cannot contain God. He also adds a fourth level between heaven and temple by asking if God will dwell on earth, which makes the idea of dwelling in a single house even more unimaginable. ${ }^{45}$ Job 25.5-6 provides a particularly rich example of a complex, multistep qal wahomer. The basic form argues that even

41. Antoine Arnauld and Pierre Nicole, The Port-Royal Logic (trans. Thomas Spencer Baynes; Edinburgh: James Gordon, 1861), p. 229.

42. Edward H. Madden, 'The Enthymeme: Crossroads of Logic, Rhetoric, and Metaphysics', Philosophical Review 61.2 (1952), pp. 368-376 (374).

43. Louis Jacobs, 'The Qal Va-Homer Argument in the Old Testament', Bulletin of the School of Oriental and African Studies 35 (1972), pp. 221-26 (223); Wilhelm Bacher, Die exegetische Terminologie der jüdischen Traditionsliteratur, erster Teil: die bibelexegetische Terminologie der Tannaiten (Leipzig: J.C. Hinrichs, 1899), p. 174.

44. James L. Kugel (The Idea of Biblical Poetry: Parallelism and its History [New Haven: Yale University Press, 1981], p. 10) explores Eccl. 7.1 as one delightful example.

45. I thank Matthew Lynch for suggesting this example. Isa. 66.1 is similar, though with only three steps in the chain: heaven, earth, and temple (Jacobs, 'Qal Va-Homer', p. 224). 
celestials lack brightness and purity in God's sight, so how much less a human. But the human is then brought even lower via equation with worms and maggots. This three-level comparison contains an implicit fourth level because God is not only the one evaluating stars, moon, and humans, but is himself the extreme example of brightness (cf. v. 3) and purity. Furthermore, the parallelism invokes two different attributes from the two celestials - brightness from the moon and purity from the starsnot unlike the way Jon. 4.10-11 draws features from both the qiqayon and Nineveh. While these examples are not identical in form to YHWH's argument in Jonah, they do illustrate comparable rhetorical creativity in extending the basic qal wahomer form.

\section{Canonical and Narratival Context}

For those arguing that the book of Jonah focuses on YHWH's interest in and compassion for the nations, the rarity of this theme in the Hebrew Bible places a considerable burden of proof upon them. On the other hand, both the narratival and canonical contexts of the book significantly accord with a focus on Israel's need to be responsive under YHWH's threat of destruction, as the sailors and Ninevites have been.

In terms of narratival setting, the prophet Jonah is connected to the reign of Jeroboam II in $2 \mathrm{Kgs}$ 14.23-29. While some commentators note the unmerited reprieve granted Israel here, the connection is usually wielded as an analogy for YHWH's grace toward Nineveh. ${ }^{46}$ However, the connection also works the other way: as Nineveh has avoided catastrophe through responsiveness to YHWH, so should Israel. The charge of Nineveh's evil (רעה) rising up before YHWH in 1.2 accords with the charge against Jeroboam II of doing evil (הרע) in the sight of YHWH (2 Kgs 14.24), a regular charge of the historian against Israel's kings. Not much later, the theological epitaph of the northern kingdom cites their refusal to heed the prophetic warning to repent: 'Yet YHWH warned Israel and Judah by every prophet and every seer, saying "Turn from your evil ways...” (שבו מדרכיכם הרעים). They would not listen but were stubborn...' (2 Kgs 17.13-14). The narrator of Jonah records YHWH gaining from Nineveh just what Kings attests Israel refused to do: 'When God saw what they did, how they turned from their evil way (שבו) מדרכם הרעה), God changed his mind about the calamity' (Jon. 3.10; cf. also v. 8). Nineveh provides an example from which Israel should learn.

46. E.g. Fretheim, Jonah, p. 41. 
In terms of canonical context, three texts are regularly cited for verbal and thematic links to Jonah: Jeremiah 18; 36; and Joel 2. All three of these intertexts support the proposed reading of Jonah. Jeremiah 18 is a programmatic text about prophetic messages and responsiveness. While applicable to any nation or kingdom (vv. 7,9), the primary entity receiving the prophetic message here is Israel (vv. 6, 11). As I argue for the book of Jonah, a discussion of YHWH's dealings with other nations aims to motivate Israel. Jeremiah 36, which depicts the confrontation between Baruch who bears Jeremiah's prophecies and Jehoiakim king of Judah, bears strong thematic and verbal connections to Jonah 3, as is often cited. ${ }^{47}$ YHWH commissions Jeremiah to prepare a scroll containing his words spoken against (על; cf. Jon. 1.2) Israel and Judah (and all the nations) so that 'it may be (אולי; cf. Jon. 1.9) that when the house of Judah hears of all the disasters (הרעה; cf. Jon. 1.7-8; 3.10) that I intend to do to them, all of them may turn from their evil ways (מדרכו הרעה ישובו איש; cf. Jon. 3.8, 10; Jer. 36.7), so that I may forgive their iniquity and their sin' (vv. 2-3). Threats of disaster are intended to motivate change and the aversion of the disaster, as the sailors and Ninevites have recognized. In sharp distinction to the king of Nineveh's instantaneous and totalizing response of fear and repentance under the prophetic threat - marked by shedding his royal garments (Jon. 3.6) - Jehoiakim dramatically feeds the prophetic word into the fire (v. 23) and refuses to fear or tear his garments (v. 24). Finally, in Joel 2.1-17 YHWH heads the army to destroy Israel (v. 11). This image of destruction is interrupted by an appeal to Jerusalem to return (שוב) to YHWH. This prophetic appeal is justified by the creedal assertion that 'he is gracious and merciful, slow to anger, and abounding in steadfast love, and relents from punishing' (v. 13). The wording is identical to Jonah's 'complaint' in 4.2 and moreover the only place where such appears together with 'relents from punishing', which adds an additional merciful element to the formula of Exod. 34.6-7, an addition pertinent to both Joel and Jonah. YHWH is not presumed to relent but such mercy is marked with 'who knows...?' (' יודע, v. 14), as with the Ninevite king (Jon. 3.9).48 The entire population

47. E.g. Yvonne Sherwood, A Biblical Text and its Afterlives: The Survival of Jonah in Western Culture (Cambridge: Cambridge University Press, 2001), p. 263; Sasson, Jonah, p. 247.

48. If Jonah is intentionally referring to Jer. 36 and Joel 2, it is interesting that the 'perhaps' (אולי) of Jer. 36 is spoken by the sailors and the 'who knows...?' of Joel 2 is spoken by the Ninevite king. 
is called to a solemn assembly, a fast (vv. 15-16; cf. Jon. 3.5), and an appeal that YHWH spare them (חום, v. 17; cf. Jon. 4.10-11). These canonical resonances reinforce the idea that the book of Jonah is a voice in the center of a prophetic chorus calling Israel to recognize its perilous state before YHWH.

\section{Discussion}

The primary theme of the book of Jonah revolves around responsiveness to YHWH. While everyone and everything else responds to YHWH, with the sailors and Ninevites particularly cognizant of the risk of crossing the divine will, Jonah sticks out as the lone rebel, seemingly unconcerned about his own peril. His twisted speech throughout the book shows a peculiar logic at work that half understands what it means to live under YHWH, but is bogglingly unaware of the implications. But this is no simple condemnation of Israel in a supersessionist move toward YHWH transferring attention to the nations. ${ }^{49}$ Neither the Ninevites nor the sailors replace Jonah, who remains the focal point of YHWH's interest to the end. They are mere props on the stage, responsive foils to Jonah's recalcitrance, tools in the service of YHWH's relationship with Israel, just as Nebuchadnezzar, Cyrus, and indeed Assyria were understood to be.

Although I have argued that YHWH's conflict with Nineveh is to be ordered underneath the conflict with Jonah, the particular choice of the Assyrian imperial capital as the recipient of YHWH's reprieve should, of course, not be disregarded. The people of YHWH suffered tremendously under the various imperial powers. This city of Nineveh may well be YHWH's own qiqayon, an ephemeral entity, not significantly toiled over or caused to grow, but useful within the divine purpose. Jonah desires his plant to continue living because, despite its triviality, it is useful to him in the burning sun. Like Jonah's qiqayon, Nineveh and other imperial powers can be used by YHWH for either protection or chastisement. As Abravanel dared to suggest, Nineveh - compliant under YHWH's will in unrecognized ways - will be useful to YHWH as a weapon for the brutal chastisement of both Israel and Judah. ${ }^{50}$ This is where the message of the book of Jonah becomes most difficult and cannot be reduced to a simple inspiring idea, because responsiveness to YHWH is no simple matter. The

49. On this theme in the Christian reception history of Jonah, see Sherwood, Afterlives, pp. 21-32, 64-74.

50. Sherwood, Afterlives, pp. 127-28. 
book begins with Jonah refusing to join YHWH in his mediatorial mission to moderate Nineveh's wickedness. Jonah likely wants YHWH to destroy the wicked city that so threatens his own land and does not want to be the prophetic voice that averts the threatened wrath. But this is only the tip of the book's iceberg, because Israel (whether northern or southern kingdom, or Persian Yehud) regularly lives under YHWH's threat because of its failure to respond to YHWH's will, in both the cultic (cf. the sailors) and the moral (cf. Nineveh) spheres. While YHWH's people may perceive the imperial powers to be the loci of their deepest dangers, their most critical choice concerns their willingness to focus on YHWH's demands. Jonah's refusal to accede to YHWH's plan to 'overturn' Nineveh is understandable on the level of pragmatic politics, but is also completely unacceptable. As Jonah makes his way forward, his and Israel's task is much more difficult than sailors responding to stormy seas or Ninevites turning from evil ways, as covenant life lived under YHWH carries such heavy demands as preventing the destruction of the people who might then turn and destroy. Even though Israel seems to live constantly in storms and under prophetically spoken divine threats, the way forward demands acceptance of YHWH's dangerous ways. As Jonah repeatedly voices a preference for death rather than life under YHWH, so Jeremiah characterized Israel's fatalistic reasoning: 'But they say, "It is no use! We will follow our own plans, and each of us will act according to the stubbornness of our evil will"' (Jer. 18.12). This is not far from Jonah's own conviction that drowning is better than going to Nineveh, that death in the desert is more tolerable than living in a world where YHWH relents from destroying the wicked city. But Israel's life under YHWH demands courageous responsiveness to his surprising and challenging ways. 